
\title{
$\angle S$ Research Suare \\ Preoperative C-reactive Protein as a Prognostic Factor in Stage IV Colorectal Cancer
}

\section{Hiroka Kondo ( $\nabla$ hirokak@saitama-med.ac.jp )}

Saitama Medical University International Medical Center https://orcid.org/0000-0003-1416-4383

\section{Yasumitsu Hirano}

Saitama Ika Daigaku Kokusai Iryo Center Hokatsuteki Gan Center

\section{Toshimasa Ishii}

Saitama Ika Daigaku Kokusai Iryo Center Hokatsuteki Gan Center

\section{Shintaro Ishikawa}

Saitama Ika Daigaku Kokusai Iryo Center Hokatsuteki Gan Center

\section{Takatsugu Fujii}

Saitama Ika Daigaku Kokusai Iryo Center Hokatsuteki Gan Center

Masahiro Asari

Saitama Ika Daigaku Kokusai Iryo Center Hokatsuteki Gan Center

\section{Atsuko Kataoka}

Saitama Ika Daigaku Kokusai Iryo Center Hokatsuteki Gan Center

\section{Masahiro Kataoka}

Saitama Ika Daigaku Kokusai Iryo Center Hokatsuteki Gan Center

\section{Satoshi Shimamura}

Saitama Ika Daigaku Kokusai Iryo Center Hokatsuteki Gan Center

\section{Shigeki Yamaguchi}

Saitama Ika Daigaku Kokusai Iryo Center Hokatsuteki Gan Center

\section{Research}

Keywords: CRP, colorectal cancer, stage IV

Posted Date: August 19th, 2020

DOI: https://doi.org/10.21203/rs.3.rs-60965/v1

License: (1) This work is licensed under a Creative Commons Attribution 4.0 International License. Read Full License 
Version of Record: A version of this preprint was published at International Surgery on January 21 st, 2021. See the published version at https://doi.org/10.9738/INTSURG-D-20-00035.1. 


\section{Abstract}

Background: A prognosis for stage IV colorectal cancer is generally poor. As a result, the development of an appropriate treatment strategy for each individual with this disease within a limited time frame is important. In various malignancies, preoperative high C-reactive protein (CRP) levels may be a possible poor prognostic factor. However, few studies have been made of CRP in stage IV cases of colorectal cancer so it is unclear whether CRP is a useful prognostic marker for this disease. Thus, the purpose of this study was to clarify the relationship between the preoperative CRP level and the prognosis of stage IV colorectal cancer.

Patients and methods: Between April 2007 and December 2015, 384 patients with stage IV colorectal cancer who underwent primary resection were included. Patients were divided into high (HCG) and low (LCG) CRP groups based on a preoperative CRP cut-off value of ${ }^{3} 1.0 \mathrm{mg} / \mathrm{dL}$. Postoperative short- and long-term results were examined retrospectively.

Results: Preoperative carcinoembryonic antigen (CEA) levels were higher in HCG; the number of R0 surgical resections of distant metastases was smaller. The 5 -year survival rate was $24.6 \%$ for HCG and $36.7 \%$ for LCG, indicating the survival rate for HCG was lower. A multivariate analysis of factors affecting survival rates identified $\mathrm{CRP}>1.0$, histopathological type, positive venous infiltration, and R0 inoperability as risk factors. The rate of $\mathrm{RO}$ resection was higher in LCG. Concerning R0 resection patients, differences between HCG and LCG with regard to background factors, including preoperative CEA levels, were not found. In terms of long-term survival, a significant difference in overall survival between the two groups was not observed. The study was limited to patients who were unable to undergo R0 surgery. Preoperative CEA levels were higher in HCG while the postoperative chemotherapy induction rate was lower. HCG also showed a significantly lower survival rate than LCG. Multivariate analysis showed that CRP levels above $1.0 \mathrm{mg} / \mathrm{dL}$, poorly differentiated histopathology, and the absence of chemotherapy were risk factors affecting overall survival.

Conclusion: These results suggest that the preoperative CRP level may be a useful biomarker for the prognosis of incurable stage IV colorectal cancer.

\section{Introduction}

Treatment outcomes for stage IV colorectal cancer are generally poor. For example, in unresectable colorectal cancer, the median survival time (MST) without drug therapy is about 8 months [1]. Recent advances in drug therapy have extended MST to more than 30 months although this disease remains difficult to cure in most patients [2] [3] [4]. Because of a limited time with which to act, it is extremely important to formulate an appropriate treatment strategy. However, to date, the prognostication of each patient with stage IV colorectal cancer is thought to be difficult.

A high C-reactive protein (CRP) value in a preoperative examination is suggested to be a poor prognostic factor in various malignant tumors such as gastric [5], lung [6], pancreatic [7, 8], and colon cancers [9]. 
However, most of these reports are on radically treated cases, with few reports on stage IV cases [10] [11] [12] [13] [14]. It is, therefore, unclear whether the CRP level can be a useful prognostic marker for stage IV colorectal cancer. In addition, stage IV colorectal cancer has a wide variety of medical conditions, including the metastatic organs involved, the number of metastases, and whether it is curable or incurable. The purpose of this study is to clarify the relationship between preoperative CRP levels and the prognosis of stage IV colorectal cancer.

\section{Patients And Methods}

Between April 2007 and December 2015, a total of 384 patients with stage IV colorectal cancer underwent primary resection at Saitama Medical University International Medical Center. All patients were monitored using a standard Japanese postoperative surveillance program. Patients were divided into either a high CRP group (HCG) with preoperative CRP values of $\geq 1.0 \mathrm{mg} / \mathrm{dL}$ or a low CRP group (LCG). Operative outcomes included surgical approach, operating time, blood loss, whether or not an R0 surgical resection was possible, and histopathological diagnosis. We also assessed postoperative complications, and postoperative hospital stays as short-term clinical outcomes. Five-year cancer-specific and overall survival rates served as long-term oncologic outcomes. In this study, short- and long-term outcomes in HCG and LCG were compared retrospectively.

All statistical analyses were performed using the SPSS software package (SPSS version 25: IBM, Tokyo, Japan). For statistical analysis, we performed chi-squared and Mann-Whitney $U$ tests to examine differences between the two groups. The cumulative survival rate was analyzed with Kaplan-Meier and log-rank tests. $P<0.05$ was considered a statistically significant difference.

\section{Results}

Patient backgrounds are shown in Table 1. There were 107 cases of HCG and 277 cases of LCG. HCG consisted of 73 males and 34 females while LCG was made up of 172 males and 105 females. The average ages in each group were 67 and 65 years, respectively. There were no significant differences between HCG and LCG in terms of age, sex, the presence or absence of double or multiple cancers, preoperative American Society of Anesthesiologists physical status (ASA-PS), BMI (body mass index), and history of abdominal surgery. Only preoperative carcinoembryonic antigen (CEA) values were significantly higher in HCG. Table 2 shows short-term postoperative outcomes. A significant difference between HCG and LCG in the rate of laparoscopic surgery, operation time, blood loss, postoperative complication rate, and postoperative hospital stay was not observed. A difference in histopathological findings between these two groups was also not found. However, the number of cases with an R0 surgical resection of distant metastasis was significantly smaller in HCG. Figure 1 shows a Kaplan-Meier survival curve. The 3-year survival rate was $33.9 \%$ for HCG and $49.7 \%$ for LCG, while the 5 -year survival rate was $24.6 \%$ for HCG and $36.7 \%$ for LCG. This indicated a significantly lower survival rate for HCG ( $p<$ 0.001). Multivariate analysis of factors affecting the survival rate showed that a CRP value $\geq 1.0$ (hazard ratio $[\mathrm{HR}]=0.718 ; 95 \%$ confidence interval $[\mathrm{Cl}]=0.54-0.954 ; p=0.022)$, poor histopathological type $(\mathrm{HR}=$ 
$0.458 ; 95 \% \mathrm{Cl}=0.314-0.667 ; p<0.001)$, positive venous invasion $(\mathrm{HR}=0.602 ; 95 \% \mathrm{Cl}=0.389-0.931 ; p=$ $0.023)$, and whether an $\mathrm{RO}$ surgical resection was undertaken $(\mathrm{HR}=0.19 ; 95 \% \mathrm{Cl}=0.132-0.274 ; p<0.001)$ were risk factors (Table 3).

In the present study, an R0 surgical resection was performed in 122 cases (31.8\%). Eighteen cases (16.8\%) had an R0 resection in HCG, and 104 cases (37.5\%) in LCG. The proportion of R0 resections was significantly higher in LCG. The background and short-term postoperative outcomes of patients with an RO resection are shown in Tables 4 and 5. A significant difference between HCG and LCG in background factors, including preoperative CEA value, was not noted. In terms of surgical treatment, the proportion of laparoscopic surgeries was lower in HCG. Accordingly, the amount of estimated blood loss was also larger in HCG. However, a significant difference was not noted between the two groups in regard to the postoperative complication rate, the length of postoperative hospital stays, and histopathological evaluation. As for long-term survival, there was no significant difference in overall survival between the two groups in patients with an R0 resection (Fig. 2).

We also examined only those patients who underwent palliative surgery. Two hundred and sixty-two patients were unable to undergo R0 surgical resection in this series. Similar to the results of the overall stage IV study, many cases existed in HCG that showed a high CEA level within the patient background. Differences did not exist concerning age, sex, ASA-PS, BMI, and other variables listed in Table 6. In postoperative short-term results, as shown in Table 7, postoperative chemotherapy was introduced to $67.4 \%$ of patients in HCG and $83.8 \%$ of patients in LCG $(p=0.002)$. Comparing overall survival rates, HCG had significantly lower survival rates than LCG (Fig. 3). Multivariate analysis showed that CRP values above $1.0 \mathrm{mg} / \mathrm{dL}$, poorly differentiated histopathology, and the absence of chemotherapy were risk factors affecting overall survival (Table 8).

\section{Discussion}

CRP is an acute-phase protein that is synthesized and secreted by the liver and is recognized as part of the inflammatory response [15]. CRP is useful for predicting complications after the intestinal resection of malignant tumors [15] and in the prognosis of patients who have undergone surgical resection of malignant tumors [7] [8] [9] [16] [17] [18] [19]. Increased CRP is observed in many conditions such as infection, inflammation, malignant tumors, and trauma; previous studies have suggested a link between inflammation and cancer. In addition to CRP, other indicators of inflammation include the Glasgow prognostic score, calculated from CRP and albumin, the neutrophil-to-lymphocyte ratio, interleukin-6, matrix metalloproteinase-9, and other variables; their relationship with the degree of malignant tumor progression and prognosis has been described [20] [21]. Other studies have demonstrated that the CEA value correlates with the prognosis of colorectal cancer [22] [23]. In the present study, patients in HCG with palliative surgery showed a significantly high CEA. However, HCG patients who underwent an RO surgical resection did not show a significantly high CEA and CEA was not found to be a prognostic factor in our study. 
In short-term outcomes, univariate analysis revealed that a small number of people could perform an R0 surgical resection with HCG. In stage IV colorectal cancer, the ability to perform R0 surgery is also a prognostic factor [24]. Few cases exist in which an R0 surgical resection is possible in HCG, resulting in a poor prognosis. In addition to the high CRP value in multivariate analysis, the inability to perform an R0 surgical resection was also a factor that reduced the survival rate.

In this study, HCG patients with palliative surgery showed a significantly lower chemotherapy induction rate. Pre-chemotherapy CRP levels help predict prognosis in patients with colorectal cancer receiving oxaliplatin-based chemotherapy [19]. Chemotherapy is the most important treatment for unresectable colorectal cancer, suggesting that the low induction rate of chemotherapy in HCG may contribute to the decrease in survival rate observed.

Our results indicate that preoperative CRP levels were not useful for a subsequent prognosis in patients with an R0 surgical resection. Therefore, it is important to aim for an R0 surgical resection, regardless of the CRP level, if possible. If curative surgical resection cannot be performed in patients with high preoperative CRP levels and a poor prognosis, it is important to consider treatment strategies. CRP levels before treatment may be a useful biomarker for prudent decision making if difficulty exists in performing an $\mathrm{RO}$ surgical resection in patients with stage IV colorectal cancer.

\section{Conclusion:}

These results suggest that the preoperative CRP level may be a useful biomarker for the prognosis of incurable stage IV colorectal cancer.

\section{Abbreviations}

ASA-PS: American Society of Anesthesiologists physical status

BMl: Body mass index

Cl: confidence interval

CRP: C-reactive protein

HCG: high CRP group

HR: hazard ratio

LCG: low CRP group

\section{Declarations}

Ethics approval and consent to participate: 
All study participants provided their informed consent. The study design was approved by the Ethics Committee of Saitama Medical University International Medical Center (Number: 19-149)

\section{Consent for publication:}

All patients agreed to make their personal medical data available for research and publications.

\section{Availability of data and materials:}

Not applicable

\section{Competing interests:}

The authors declare that they have no competing interests.

\section{Funding:}

The authors declare that they have no funding.

\section{Authors' contributions:}

HK drafted this manuscript under the supervision of YH and SY. The other contributors were tasked with content review. All authors have read and approved the final document.

\section{Acknowledgments:}

The authors thank the experts at BioMed Proofreading for English copyediting.

\section{References}

1. Saito H, Kono Y, Murakami Y, Shishido Y, Kuroda H, Matsunaga T, et al.: Prognostic Significance of the Preoperative Ratio of C-Reactive Protein to Albumin and Neutrophil-Lymphocyte Ratio in Gastric Cancer Patients. World J Surg 2018, 42(6):1819-1825.

2. Okada S, Shimomura M, Tsunezuka H, Teramukai S, Ishihara S, Shimada J, et al.: Prognostic Significance of Perioperative C-Reactive Protein in Resected Non-Small Cell Lung Cancer. Semin Thorac Cardiovasc Surg 2020.

3. Kim NH, Kim HJ: Preoperative risk factors for early recurrence in patients with resectable pancreatic ductal adenocarcinoma after curative intent surgical resection. Hepatobiliary Pancreat Dis Int 2018, 17(5):450-455.

4. Haruki K, Shiba H, Shirai Y, Horiuchi T, Iwase R, Fujiwara Y, et al.: The C-reactive Protein to Albumin Ratio Predicts Long-Term Outcomes in Patients with Pancreatic Cancer After Pancreatic Resection. World J Surg 2016, 40(9):2254-2260. 
5. Lumachi F, Basso SM, Santeufemia DA, Ermani M, Lo Re G, Chiara GB: Preoperative serum C-reactive protein and its prognostic significance in patients with stage III-IV colorectal cancer. Anticancer Res 2014, 34(12):7263-7266.

6. Shibutani M, Maeda K, Nagahara H, Noda E, Ohtani H, Nishiguchi Y, et al.: Prognostic significance of the preoperative serum C-reactive protein level in patients with stage IV colorectal cancer. Surg Today 2015, 45(3):315-321.

7. Selby J, Prabhudesai A: Can C-reactive protein predict the severity of a post-operative complication after elective resection of colorectal cancer? Int J Colorectal Dis 2014, 29(10):1211-1215.

8. Ishizuka M, Nagata H, Takagi K, Iwasaki Y, Shibuya N, Kubota K: Clinical Significance of the CReactive Protein to Albumin Ratio for Survival After Surgery for Colorectal Cancer. Ann Surg Oncol 2016, 23(3):900-907.

9. Matsumoto Y, Kosuga T, Konishi T, Kudou M, Shoda K, Arita T, et al.: [Prognostic Value of Preoperative Serum C-Reactive Protein Level in Gastric Cancer]. Gan To Kagaku Ryoho 2019, 46(10):1623-1625.

10. Takasu C, Shimada M, Kurita N, Iwata T, Nishioka M, Morimoto S, et al.: Impact of C-reactive protein on prognosis of patients with colorectal carcinoma. Hepatogastroenterology 2013, 60(123):507-511.

11. McMillan DC, Wotherspoon HA, Fearon KC, Sturgeon C, Cooke TG, McArdle CS: A prospective study of tumor recurrence and the acute-phase response after apparently curative colorectal cancer surgery. Am J Surg 1995, 170(4):319-322.

12. Kersten C, Louhimo J, Algars A, Lahdesmaki A, Cvancerova M, Stenstedt K, et al.: Increased C-reactive protein implies a poorer stage-specific prognosis in colon cancer. Acta Oncol 2013, 52(8):1691-1698.

13. Rasic I, Rebic V, Rasic A, Aksamija G, Radovic S: The Association of Simultaneous Increase in Interleukin-6, C Reactive Protein, and Matrix Metalloproteinase-9 Serum Levels with Increasing Stages of Colorectal Cancer. J Oncol 2018, 2018:2830503.

14. Kubo H, Murayama Y, Arita T, Kuriu Y, Nakanishi M, Otsuji E: The Prognostic Value of Preoperative Neutrophil-to-Lymphocyte Ratio in Colorectal Cancer. World J Surg 2016, 40(11):2796-2802.

15. Desch CE, Benson AB, 3rd, Somerfield MR, Flynn PJ, Krause C, Loprinzi CL, et al.: Colorectal cancer surveillance: 2005 update of an American Society of Clinical Oncology practice guideline. J Clin Oncol 2005, 23(33):8512-8519.

16. Duffy MJ, van Dalen A, Haglund C, Hansson L, Klapdor R, Lamerz R, et al.: Clinical utility of biochemical markers in colorectal cancer: European Group on Tumour Markers (EGTM) guidelines. Eur J Cancer 2003, 39(6):718-727.

17. Huang SC, Lin JK, Lin TC, Chen WS, Yang SH, Wang HS, et al.: Concordance of Carcinoembryonic Antigen Ratio and Response Evaluation Criteria in Solid Tumors as Prognostic Surrogate Indicators of Metastatic Colorectal Cancer Patients Treated with Chemotherapy. Ann Surg Oncol 2015, 22(7):2262-2268.

18. Hotokezaka M, Jimi S, Hidaka H, Ikeda T, Uchiyama S, Nakashima S, et al.: Factors influencing outcome after surgery for stage IV colorectal cancer. Surg Today 2008, 38(9):784-789. 


\section{Tables}

Table 1

Clinical characteristics in all patients

\begin{tabular}{|c|c|c|c|}
\hline & High CRP Group & Low CRP Group & P-value \\
\hline $\mathrm{n}$ & 107 & 277 & \\
\hline \multicolumn{4}{|l|}{ Gender } \\
\hline Male & $73(68.2 \%)$ & $172(62.1 \%)$ & \\
\hline Female & $34(31.8 \%)$ & $105(37.9 \%)$ & 0.262 \\
\hline Age (years) & $67.27 \pm 10.18$ & $65.39 \pm 11.05$ & 0.136 \\
\hline \multicolumn{4}{|c|}{ Double cancers } \\
\hline Yes & $8(7.5 \%)$ & $22(7.9 \%)$ & \\
\hline No & $99(92.5 \%)$ & $255(92.1 \%)$ & 0.879 \\
\hline \multicolumn{4}{|c|}{ Multiple cancers } \\
\hline Yes & $9(8.4 \%)$ & $19(6.9 \%)$ & \\
\hline No & $98(91.6 \%)$ & $258(93.1 \%)$ & 0.600 \\
\hline \multicolumn{4}{|l|}{ ASA-PS } \\
\hline 1 & $41(38.3 \%)$ & $103(37.5 \%)$ & \\
\hline 2 & $51(47.7 \%)$ & $147(53.5 \%)$ & \\
\hline 3 & $15(14.0 \%)$ & $25(9.1 \%)$ & 0.317 \\
\hline \multicolumn{4}{|c|}{ Previous abdominal surgery } \\
\hline Yes & $34(31.8 \%)$ & $101(36.5 \%)$ & \\
\hline No & $73(68.2 \%)$ & $176(63.5 \%)$ & 0.389 \\
\hline \multicolumn{4}{|c|}{ CEA value $5.0 \mathrm{ng} / \mathrm{mL}$} \\
\hline$\geqq 5.0 \mathrm{ng} / \mathrm{mL}$ & $91(85.0 \%)$ & $197(71.1 \%)$ & \\
\hline$<5.0 \mathrm{ng} / \mathrm{mL}$ & $16(15.0 \%)$ & $80(28.9 \%)$ & 0.005 \\
\hline $\mathrm{BMI} \mathrm{kg} / \mathrm{m}^{2}$ & $22.21 \pm 3.83$ & $22.54 \pm 3.55$ & 0.404 \\
\hline
\end{tabular}


Table 2

Short-term outcomes in all patients

\begin{tabular}{|c|c|c|c|}
\hline & High CRP Group & Low CRP Group & P-value \\
\hline $\mathrm{n}$ & 107 & 277 & \\
\hline \multicolumn{4}{|l|}{ Laparoscopic surgery } \\
\hline Yes & $62(57.9 \%)$ & $189(68.2 \%)$ & \\
\hline No & $45(42.1 \%)$ & $88(31.8 \%)$ & 0.058 \\
\hline Operation time (min) & $216.11 \pm 90.24$ & $228.89 \pm 85.68$ & 0.064 \\
\hline Blood loss (mL) & $196.71 \pm 332.67$ & $145.70 \pm 281.87$ & 0.181 \\
\hline \multicolumn{4}{|l|}{ Postoperative complication } \\
\hline \multicolumn{4}{|l|}{ Clavien-Dindo Grade $\geqq I I$} \\
\hline Yes & $19(17.8 \%)$ & $42(15.2 \%)$ & \\
\hline No & $88(82.2 \%)$ & $235(84.8 \%)$ & 0.533 \\
\hline \multicolumn{4}{|c|}{ Urination disorder (self-catheterization) } \\
\hline Yes & $3(2.8 \%)$ & $6(2.2 \%)$ & \\
\hline No & $104(97.2 \%)$ & $271(97.8 \%)$ & 0.711 \\
\hline Postoperative hospital stay (day) & $11.30 \pm 9.67$ & $10.96 \pm 13.53$ & 0.732 \\
\hline \multicolumn{4}{|l|}{ R0 surgical resection } \\
\hline Yes & $18(16.8 \%)$ & $104(37.5 \%)$ & \\
\hline No & $89(83.2 \%)$ & $173(62.5 \%)$ & $₫ 0.001$ \\
\hline \multicolumn{4}{|l|}{ Histopathology } \\
\hline well, moderate & $92(86.0 \%)$ & 247 (89.2\%) & \\
\hline poor, mucinous & $15(14.0 \%)$ & 30 (10.8\%) & 0.384 \\
\hline \multicolumn{4}{|l|}{ Lymphatic invasion } \\
\hline Positive & $62(57.9 \%)$ & $159(57.4 \%)$ & \\
\hline Negative & $45(42.1 \%)$ & $118(42.6 \%)$ & 0.952 \\
\hline \multicolumn{4}{|l|}{ Venous invasion } \\
\hline Positive & $90(84.1 \%)$ & $244(88.1 \%)$ & \\
\hline
\end{tabular}




\begin{tabular}{|llll|}
\hline & High CRP Group & Low CRP Group & P-value \\
\hline Negative & $17(15.9 \%)$ & $33(11.9 \%)$ & 0.259 \\
\hline Tumor depth & & & \\
\hline T1-3 & $64(59.8 \%)$ & $185(66.8 \%)$ & \\
\hline T4 & $43(40.2 \%)$ & $92(33.2 \%)$ & 0.199 \\
\hline Lymph node metastasis & & & \\
\hline Positive & $82(76.6 \%)$ & $222(80.1 \%)$ & \\
\hline Negative & $25(23.4 \%)$ & $55(19.9 \%)$ & 0.504 \\
\hline Peritoneal dissemination & & & \\
\hline Positive & $26(24.3 \%)$ & $53(19.1 \%)$ & 0.262 \\
\hline Negative & $81(75.7 \%)$ & $224(80.9 \%)$ & \\
\hline CRP, C-reactive protein & & & \\
\hline
\end{tabular}


Table 3

Multivariate analysis of factors affecting survival rates

\begin{tabular}{|lllll|}
\hline & Hazard Ratio & \multicolumn{2}{l}{$95.0 \%$ Cl } & P-value \\
\hline Gender & 0.938 & 0.71 & 1.24 & 0.653 \\
\hline Age & 1.009 & 0.996 & 1.022 & 0.195 \\
\hline Double cancers & 0.96 & 0.591 & 1.56 & 0.868 \\
\hline Multiple cancers & 1.121 & 0.685 & 1.833 & 0.650 \\
\hline Clavien-Dindo Grade II or higher & 1.075 & 0.758 & 1.525 & 0.684 \\
\hline CEA $\geq 5.0$ ng/mL & 0.828 & 0.607 & 1.13 & 0.234 \\
\hline CRP $\geq 1.0$ mg/dL & 0.718 & 0.54 & 0.954 & 0.022 \\
\hline Histological type & 0.458 & 0.314 & 0.667 & $<0.001$ \\
\hline Lymphatic invasion & 0.818 & 0.62 & 1.081 & 0.158 \\
\hline Vein invasion & 0.602 & 0.389 & 0.931 & 0.023 \\
\hline Tumor depth & 0.804 & 0.609 & 1.061 & 0.124 \\
\hline Lymph node metastasis & 1.003 & 0.701 & 1.436 & 0.986 \\
\hline With peritoneal dissemination & 0.817 & 0.592 & 1.128 & 0.219 \\
\hline R0 surgical resection & 0.19 & 0.132 & 0.274 & $<0.001$ \\
\hline CEA, carcinoembryonic antigen; CRP, C-reactive protein; Cl, confidence interval \\
\hline
\end{tabular}


Table 4

Clinical characteristics in patients with $\mathrm{R} 0$ surgical resection

\begin{tabular}{|c|c|c|c|}
\hline & High CRP Group & Low CRP Group & P-value \\
\hline$n$ & 18 & 104 & \\
\hline \multicolumn{4}{|l|}{ Gender } \\
\hline Male & $12(66.7 \%)$ & $58(55.8 \%)$ & \\
\hline Female & $6(33.3 \%)$ & $46(44.2 \%)$ & 0.388 \\
\hline Age & $63.22 \pm 9.45$ & $64.71 \pm 10.66$ & 0.400 \\
\hline \multicolumn{4}{|l|}{ Double cancers } \\
\hline Yes & $1(5.6 \%)$ & $7(6.7 \%)$ & \\
\hline No & $17(94.4 \%)$ & $97(93.3 \%)$ & 0.665 \\
\hline \multicolumn{4}{|c|}{ Multiple cancers } \\
\hline Yes & $1(5.6 \%)$ & $7(6.7 \%)$ & \\
\hline No & $17(94.4 \%)$ & $97(93.3 \%)$ & 0.665 \\
\hline \multicolumn{4}{|l|}{ ASA-PS* } \\
\hline 1 & $9(50.0 \%)$ & $39(37.5 \%)$ & \\
\hline 2 & $6(33.3 \%)$ & $57(54.8 \%)$ & \\
\hline 3 & $3(16.7 \%)$ & $8(7.7 \%)$ & 0.187 \\
\hline \multicolumn{4}{|c|}{ Previous abdominal surgery } \\
\hline Yes & $6(33.3 \%)$ & $41(39.4 \%)$ & \\
\hline No & $12(66.7 \%)$ & $63(60.6 \%)$ & 0.624 \\
\hline \multicolumn{4}{|c|}{$\mathrm{CEA}^{\star \star}$ value $5.0 \mathrm{ng} / \mathrm{mL}$} \\
\hline$\geqq 5.0 \mathrm{ng} / \mathrm{mL}$ & $14(77.8 \%)$ & $66(63.5 \%)$ & \\
\hline$<5.0 \mathrm{ng} / \mathrm{mL}$ & $4(22.2 \%)$ & $38(36.5 \%)$ & 0.238 \\
\hline $\mathrm{BMI} I^{\star \star \star} \mathrm{kg} / \mathrm{m}^{2}$ & $21.41 \pm 3.43$ & $22.49 \pm 3.29$ & 0.297 \\
\hline $\begin{array}{l}\text { ASA-PS, Ameri } \\
\text { Body mass ind }\end{array}$ & logists physical & A, Carcinoemb & igen; BM \\
\hline
\end{tabular}


Table 5

Short-term outcomes in patients with $\mathrm{R} 0$ surgical resection

\begin{tabular}{|c|c|c|c|}
\hline & High CRP Group & Low CRP Group & P-value \\
\hline $\mathrm{n}$ & 18 & 104 & \\
\hline \multicolumn{4}{|l|}{ Laparoscopic surgery } \\
\hline Yes & $7(38.9 \%)$ & $67(64.4 \%)$ & \\
\hline No & $11(61.1 \%)$ & $37(35.6 \%)$ & 0.041 \\
\hline Operation time (min) & $251.28 \pm 124.55$ & $228.74 \pm 97.67$ & 0.593 \\
\hline Blood loss (mL) & $357.78 \pm 441.31$ & $193.64 \pm 358.31$ & 0.032 \\
\hline \multicolumn{4}{|l|}{ Postoperative complication } \\
\hline \multicolumn{4}{|l|}{ Clavien-Dindo Grade $\geqq I I$} \\
\hline Yes & $2(11.1 \%)$ & $13(12.5 \%)$ & \\
\hline No & $16(88.9 \%)$ & $91(87.5 \%)$ & 0.614 \\
\hline \multicolumn{4}{|c|}{ Urination disorder (self-catheterization) } \\
\hline Yes & $0(0.0 \%)$ & $2(1.9 \%)$ & \\
\hline No & $18(100.0 \%)$ & $102(98.1 \%)$ & 0.726 \\
\hline Postoperative hospital stay (day) & $10.33 \pm 5.27$ & $9.93 \pm 6.47$ & 0.575 \\
\hline \multicolumn{4}{|l|}{ Histopathology } \\
\hline Well, moderate & $15(83.3 \%)$ & $96(92.3 \%)$ & \\
\hline Poor, mucinous & $3(16.7 \%)$ & $8(7.7 \%)$ & 0.207 \\
\hline \multicolumn{4}{|l|}{ Lymphatic invasion } \\
\hline Positive & $13(72.2 \%)$ & 54 (51.9\%) & \\
\hline Negative & $5(27.8)$ & 50 (48.1\%) & 0.119 \\
\hline \multicolumn{4}{|l|}{ Venous invasion } \\
\hline Positive & 15 (83.3\%) & 85 (81.7\%) & \\
\hline Negative & $3(16.7 \%)$ & 19 (18.3\%) & 0.619 \\
\hline \multicolumn{4}{|l|}{ Tumor depth } \\
\hline $\mathrm{T} 1-3$ & $11(61.1 \%)$ & $74(71.2 \%)$ & \\
\hline
\end{tabular}




\begin{tabular}{|llll|}
\hline & High CRP Group & Low CRP Group & P-value \\
\hline T4 & $7(38.9 \%)$ & $30(28.8 \%)$ & 0.392 \\
\hline Lymph node metastasis & & & \\
\hline Positive & $13(72.2 \%)$ & $77(74.0 \%)$ & \\
\hline Negative & $5(27.8 \%)$ & $27(26.0 \%)$ & 0.512 \\
\hline Peritoneal dissemination & & & \\
\hline Positive & $2(11.1 \%)$ & $16(15.4 \%)$ & 0.481 \\
\hline Negative & $16(88.9 \%)$ & $88(84.6 \%)$ & \\
\hline CRP, C-reactive protein & & & \\
\hline
\end{tabular}


Table 6

Clinical characteristics in patients without $\mathrm{R} 0$ surgical resection

High CRP Group

Low CRP Group

P-value

$\mathrm{n}$

Gender

Male

Female

Age

Double cancers

Yes

No

Multiple cancers

Yes

No

ASA-PS*

1

2

3

Previous abdominal surgery

Yes

No

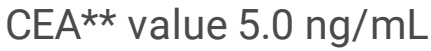

$\geqq 5.0 \mathrm{ng} / \mathrm{mL}$

$<5.0 \mathrm{ng} / \mathrm{mL}$

$\mathrm{BMI}^{\star * *} \mathrm{~kg} / \mathrm{m}^{2}$
89

$61(68.5 \%)$

$28(31.5 \%)$

$68.09 \pm 10.17$

$7(7.9 \%)$

$82(92.1 \%)$

$8(9.0 \%)$

$81(91.0 \%)$

$32(36.0 \%)$

45 (50.6\%)

$12(13.5 \%)$

$28(31.5 \%)$

$61(68.5 \%)$

$77(86.5 \%)$

$12(13.5 \%)$

$22.37 \pm 3.91$
$114(65.9 \%)$

59 (34.1\%)

0.667

$65.80 \pm 11.29$

0.105

15 (8.7\%)

158 (91.3\%)

0.824

$12(6.9 \%)$

161 (93.1\%)

0.554

$64(37.4 \%)$

$90(52.6 \%)$

$17(9.9 \%)$

0.690

$60(34.7 \%)$

113 (65.3\%)

0.601

ASA-PS, American Society of Anesthesiologists physical status; CEA, Carcinoembryonic antigen; BMI, Body mass index; CRP, C-reactive protein 
Table 7

Short-term outcomes in patients without R0 surgical resection

\begin{tabular}{|c|c|c|c|}
\hline & High CRP Group & Low CRP Group & P-value \\
\hline $\mathrm{n}$ & 89 & 173 & \\
\hline \multicolumn{4}{|l|}{ Laparoscopic surgery } \\
\hline Yes & $55(61.8 \%)$ & $122(70.5 \%)$ & \\
\hline No & $34(38.2 \%)$ & $51(29.5 \%)$ & 0.153 \\
\hline Operation time (min) & $209.00 \pm 80.67$ & $228.98 \pm 77.74$ & 0.017 \\
\hline Blood loss (mL) & $164.13 \pm 298.83$ & $116.88 \pm 219.96$ & 0.454 \\
\hline \multicolumn{4}{|l|}{ Postoperative complication } \\
\hline \multicolumn{4}{|l|}{ Clavien-Dindo Grade $\geqq I I$} \\
\hline Yes & $17(19.1 \%)$ & $29(16.8 \%)$ & \\
\hline No & $72(80.9 \%)$ & $144(83.2 \%)$ & 0.638 \\
\hline \multicolumn{4}{|c|}{ Urination disorder (self-catheterization) } \\
\hline Yes & $3(3.4 \%)$ & $4(2.3 \%)$ & \\
\hline No & $86(96.6 \%)$ & $169(97.7 \%)$ & 0.444 \\
\hline Postoperative hospital stay (day) & $11.49 \pm 10.35$ & $11.57 \pm 16.36$ & 0.939 \\
\hline \multicolumn{4}{|l|}{ Histopathology } \\
\hline Well, moderate & $77(86.5 \%)$ & $151(87.3 \%)$ & \\
\hline Poor, mucinous & $12(13.5 \%)$ & $22(12.7 \%)$ & 0.861 \\
\hline \multicolumn{4}{|l|}{ Lymphatic invasion } \\
\hline Positive & $49(55.1 \%)$ & 105 (60.7\%) & \\
\hline Negative & $40(44.9 \%)$ & 68 (39.3\%) & 0.380 \\
\hline \multicolumn{4}{|l|}{ Venous invasion } \\
\hline Positive & 75 (84.3\%) & 159 (91.9\%) & \\
\hline Negative & $14(15.7 \%)$ & $14(8.1 \%)$ & 0.058 \\
\hline \multicolumn{4}{|l|}{ Tumor depth } \\
\hline $\mathrm{T} 1-3$ & $53(59.6 \%)$ & $111(64.2 \%)$ & \\
\hline
\end{tabular}




\begin{tabular}{|llll|}
\hline & High CRP Group & Low CRP Group & P-value \\
\hline T4 & $36(40.4 \%)$ & $62(35.8 \%)$ & 0.465 \\
\hline Lymph node metastasis & & & 0.283 \\
\hline Positive & $69(78.4 \%)$ & $145(83.8 \%)$ & \\
\hline Negative & $20(22.5 \%)$ & $28(16.2 \%)$ & 0.283 \\
\hline Peritoneal dissemination & & & \\
\hline Positive & $24(27.0 \%)$ & $37(21.4 \%)$ & 0.312 \\
\hline Negative & $65(73.0 \%)$ & $136(78.6 \%)$ & \\
\hline Chemotherapy & $60(67.4 \%)$ & $145(83.8 \%)$ & \\
\hline Yes & $29(32.6 \%)$ & $28(16.2 \%)$ & 0.002 \\
\hline No & & & \\
\hline CRP, C-reactive protein & & & \\
\hline
\end{tabular}


Table 8

Multivariate analysis of factors affecting survival rate in patients without R0 surgical resection

\begin{tabular}{|lllll|}
\hline & Hazard Ratio & $95.0 \%$ & & Pl \\
\hline Gender & 1.122 & 0.827 & 1.521 & 0.459 \\
\hline Age & 1.004 & 0.990 & 1.017 & 0.604 \\
\hline Double cancers & 1.158 & 0.670 & 2.002 & 0.599 \\
\hline Multiple cancers & 1.552 & 0.884 & 2.726 & 0.126 \\
\hline Clavien-Dindo Grade $\geqq I I$ & 1.025 & 0.704 & 1.494 & 0.896 \\
\hline CEA value $\geqq 5.0$ ng/mL & 0.777 & 0.544 & 1.110 & 0.166 \\
\hline CRP $\geqq 1.0$ mg/dL & 0.724 & 0.531 & 0.986 & 0.041 \\
\hline Histological type & 0.500 & 0.327 & 0.764 & 0.001 \\
\hline Lymphatic invasion & 0.912 & 0.673 & 1.236 & 0.553 \\
\hline Venous invasion & 0.703 & 0.422 & 1.171 & 0.176 \\
\hline Tumor depth & 0.846 & 0.623 & 1.149 & 0.285 \\
\hline Lymph node metastasis & 0.717 & 0.472 & 1.089 & 0.118 \\
\hline Peritoneal dissemination & 0.792 & 0.554 & 1.133 & 0.202 \\
\hline Chemotherapy & 3.685 & 2.517 & 5.396 & $<0.001$ \\
\hline CEA, carcinoembryonic antigen; CRP, C-reactive protein; Cl, confidence interval \\
\hline
\end{tabular}

Figures 


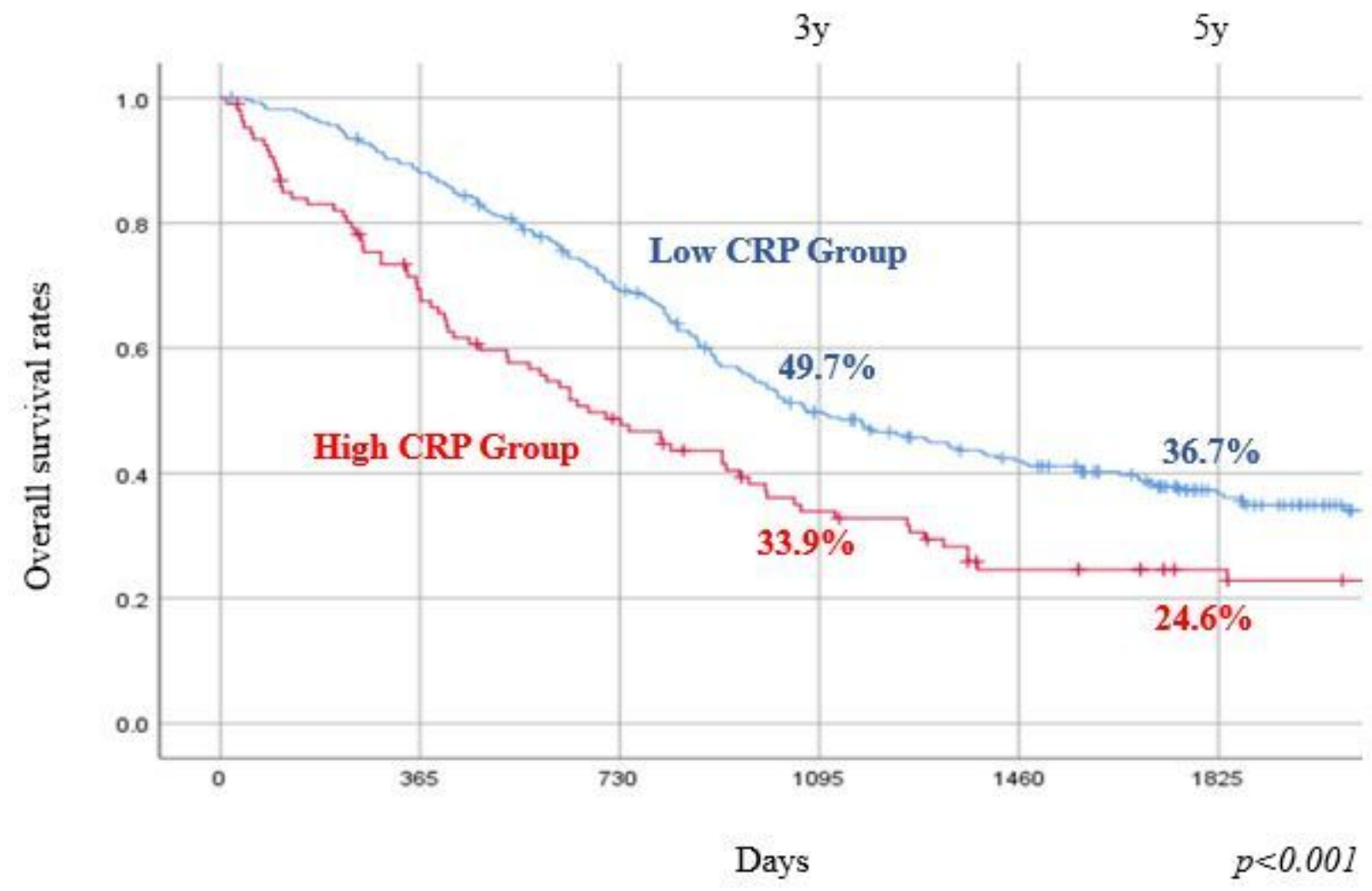

Figure 1

Kaplan-Meier survival curve 


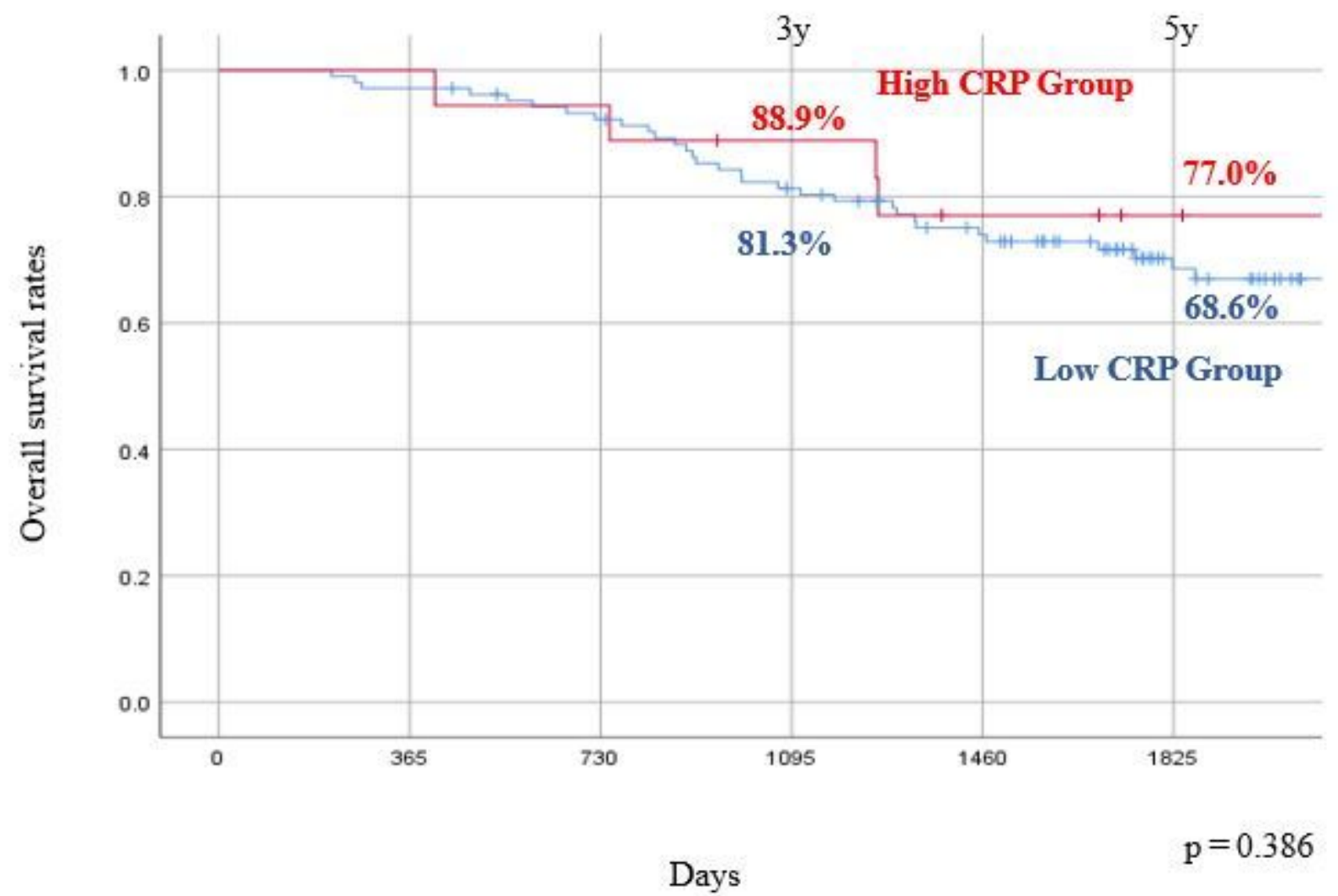

Figure 2

Kaplan-Meier survival curve in patients with R0 surgical resection 


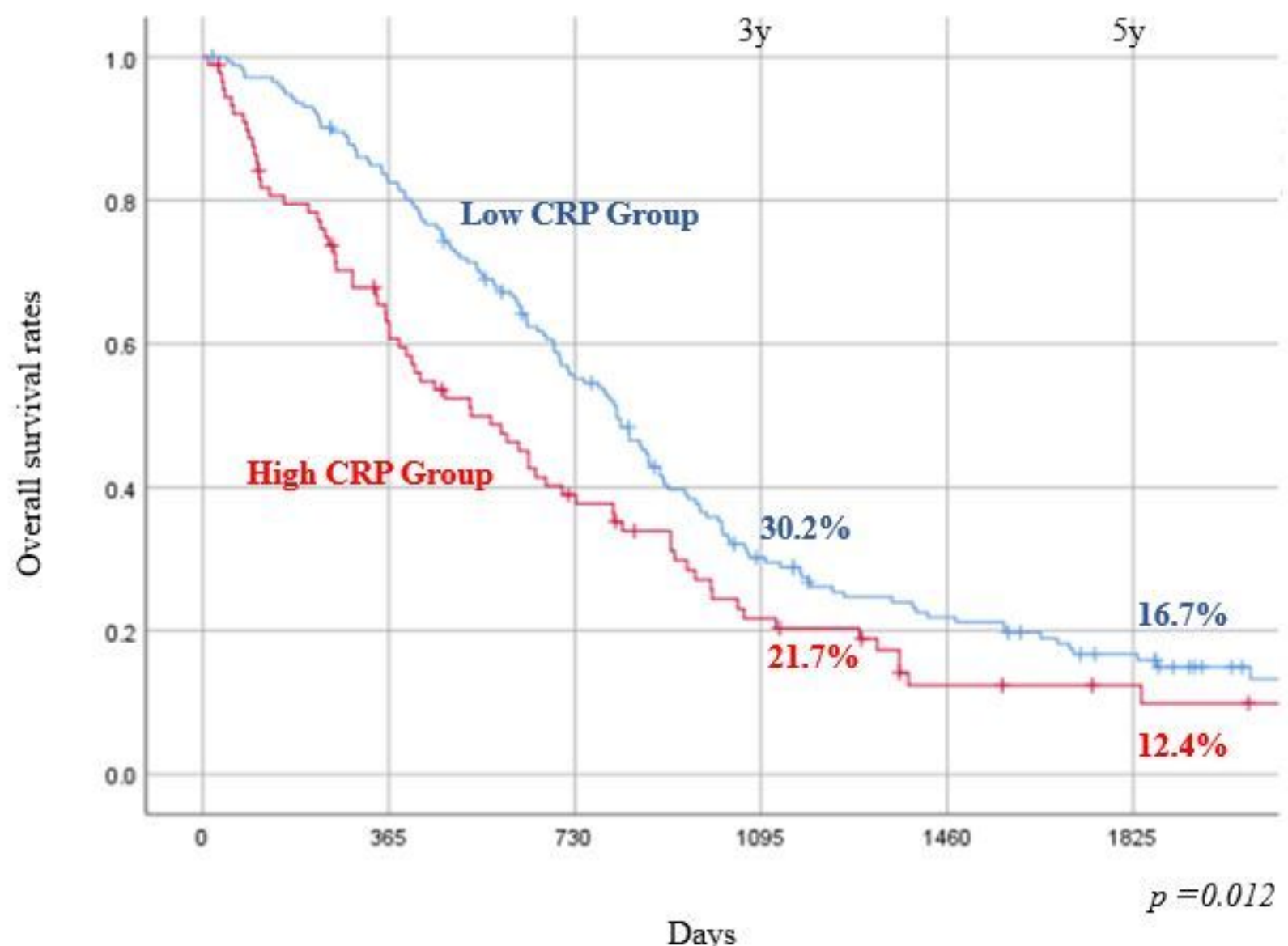

Figure 3

Kaplan-Meier survival curve in patients without R0 surgical resection 